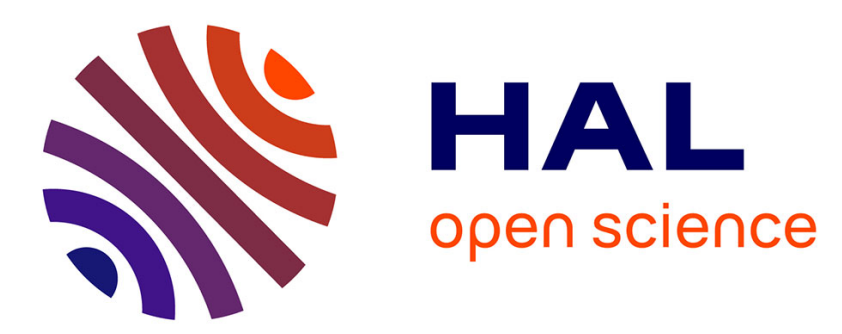

\title{
Analysis and interpretation of induced micro-seismicity by flooding of the Gardanne coal basin (Provence - Southern France)
}

Emanuela Matrullo, Isabelle Contrucci, Pascal Dominique, Mustapha

Bennani, Hideo Aochi, Jannes Kinscher, Pascal Bernard, Pascal Bigarre

\section{To cite this version:}

Emanuela Matrullo, Isabelle Contrucci, Pascal Dominique, Mustapha Bennani, Hideo Aochi, et al.. Analysis and interpretation of induced micro-seismicity by flooding of the Gardanne coal basin (Provence - Southern France). 77. EAGE Conference, Jun 2015, Madrid, Spain. ineris-01855048

HAL Id: ineris-01855048

https://hal-ineris.archives-ouvertes.fr/ineris-01855048

Submitted on 4 Sep 2018

HAL is a multi-disciplinary open access archive for the deposit and dissemination of scientific research documents, whether they are published or not. The documents may come from teaching and research institutions in France or abroad, or from public or private research centers.
L'archive ouverte pluridisciplinaire HAL, est destinée au dépôt et à la diffusion de documents scientifiques de niveau recherche, publiés ou non, émanant des établissements d'enseignement et de recherche français ou étrangers, des laboratoires publics ou privés. 


\title{
Analysis and Interpretation of Induced Micro- seismicity by Flooding of the Gardanne Coal Basin (Provence - Southern France)
}

\author{
E. Matrullo* (INERIS), I. Contrucci (INERIS), P. Dominique (BRGM - Bureau \\ de Recherches Géologiques et Minière), M. Bennani (INERIS), H. Aochi \\ (BRGM - Bureau de Recherches Géologiques et Minière), J. Kinsher \\ (INERIS), P. Bernard (IPGP - Institut de Physique du globe de Paris) \& P. \\ Bigarré (INERIS)
}

\section{SUMMARY}

Mining activity in Provence has left many underground voids that can cause land subsidence or collapses in areas of high population density. In the abandoned coal basin of Gardanne, the flooding of mine voids and fluctuations in the groundwater level induced many seismic events that have been recorded since the beginning of operational monitoring. An example is the seismic crisis of November 2012, where magnitude events $>2.5$ were felt by the population.

In this context, the objective is to understand the mechanisms of the observed seismicity. This will clarify the relationships between seismicity and rising waters in old mine working, geology and local tectonics. This general aim will be pursued, thanks the availability of the high quality dataset of recording from the dense arrays managed by INERIS and BRGM.

We will focus on the spatio-temporal distribution of the seismicity, which allows to monitor the dynamics of faulting and to estimate the extension and mode of rupture of the fracture system. The present work is based on the observation and the characterization of the microseismicity in terms of the accurate hypocentral locations, local and moment magnitudes and focal mechanisms determination in order to characterize the status of the abandoned mine. 


\section{Introduction}

Mining activity in Provence has left many underground voids that can cause land subsidence or collapses in areas of high population density. Part of these underground voids are now flooded and causes seismicity, whose strongest events were felt by the population. To mitigate these risks, a realtime microseismic monitoring was implemented in sensitive areas. And since the cessation of mining concessions in Provence, INERIS (Institut national de l'environnement industriel et des risques) has installed 5 permanent microseismic monitoring networks in the Gardanne coalfield which was operated by Charbonnages de France (Figure 1). Then, BRGM-DPSM (Bureau de recherches géologiques et minières - Département Prévention et sécurité minère) on behalf of the State, asked INERIS to continue the microseismic monitoring.

The flooding of mine voids and fluctuations in the groundwater level induced many seismic events that have been recorded since the beginning of operational monitoring. An example is the seismic crisis of November 2012, where magnitude events $>2.5$ were felt by the population (Dominique, 2014; Contrucci et al 2013; Bennani, 2012). In 2013, 5 temporary seismic stations were deployed by BRGM-DPSM specifically to monitor the activity of that particular area. Early 2014, due to an exceptionally high rainfall and achieving maximum pumping capacity in the mining area, the groundwater level of the mining reservoir rises rapidly. To anticipate the possibility of a renewed seismic activity, a temporary seismic network of 5 stations was deployed by INERIS, to complete the coverage of the existing network. Thus, the coal basin Gardanne is now monitored by five permanent microseismic stations and 10 temporary seismic stations (Figure 1). In December 2014, a new microseismic crisis was felt by people leaving in the area.

\section{Scientific objectives}

The flooding of the mine generates significant seismicity highlighted upon cessation of water pumping and observed since the beginning of the operational monitoring of the basin, confirming a high reactivity of mining voids. Strong seismic events $(>2.2)$ were recorded raising serious concerns of the people (Figure 1a). The question of events induced by the mine and flooding, or triggered events with fault re-activation, or natural events is asked. Depending on the response, the estimate of the likely maximum magnitude in the mining area may differ significantly. In this context, the objective is to engage in-depth analyses by taking advantage of the temporary network to understand the mechanisms of the observed seismicity. This will include clarifying the relationships between seismicity and rising waters in old mine working, geology and local tectonics.

We will focus on the spatio-temporal distribution of the seismic events which allows to monitor the dynamics of faulting and to estimate the extension of the fracture system. The determination of the mode of rupture (focal mechanisms) of the events is also a very important information to characterize the stability of the abandoned mine. The present work aims at a better understanding of the mechanical characteristics of the fracture system based on the observation, in particular on an accurate analysis of the low magnitude seismicity. The general aim of the work will be pursued, according to the availability of the dataset from high quality recording of the dense arrays. We will focus on the characterization of the microseismicity in terms of the accurate hypocentral locations, local and moment magnitudes and accurate focal mechanisms determination. 
(a)

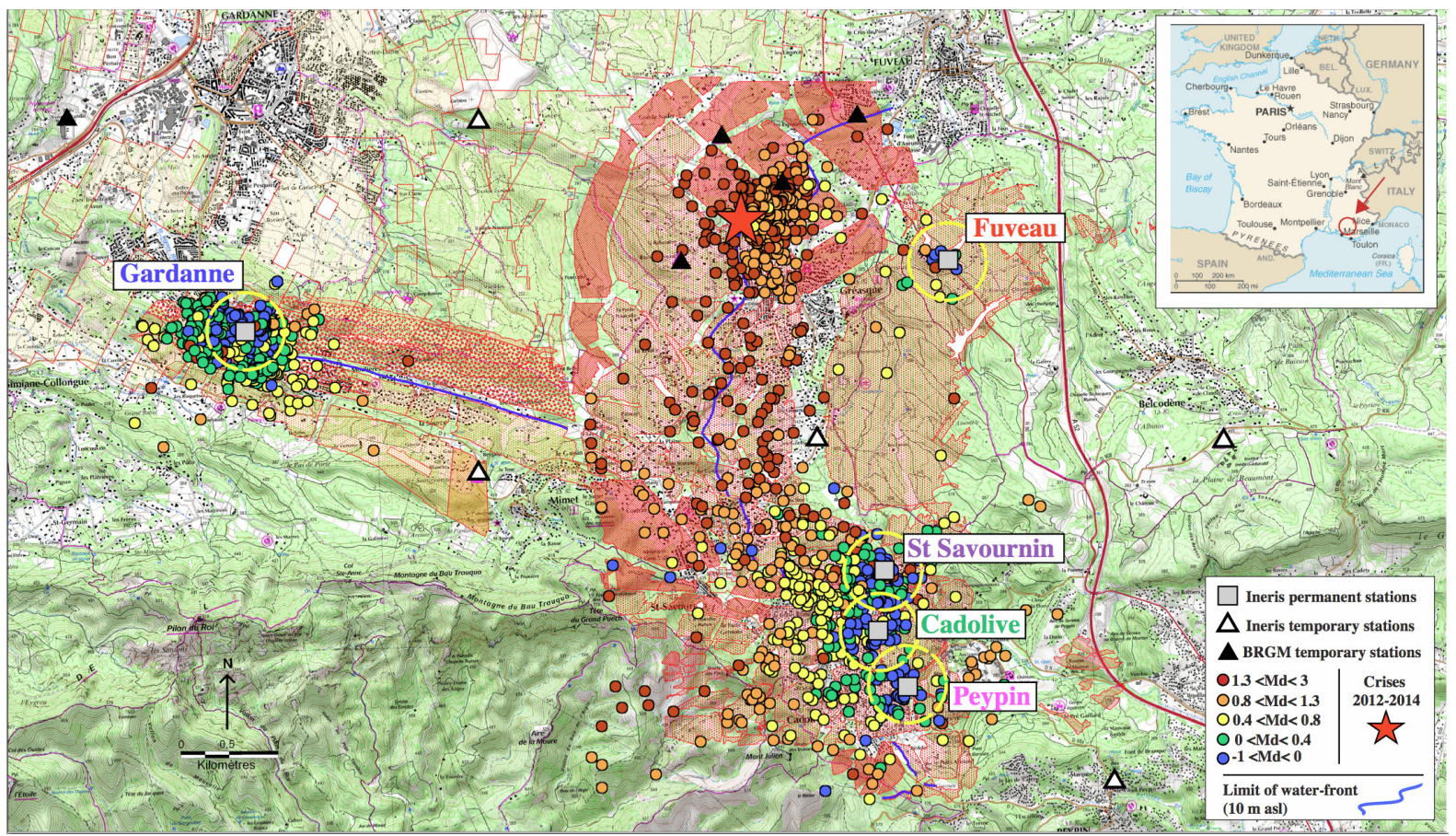

(b)

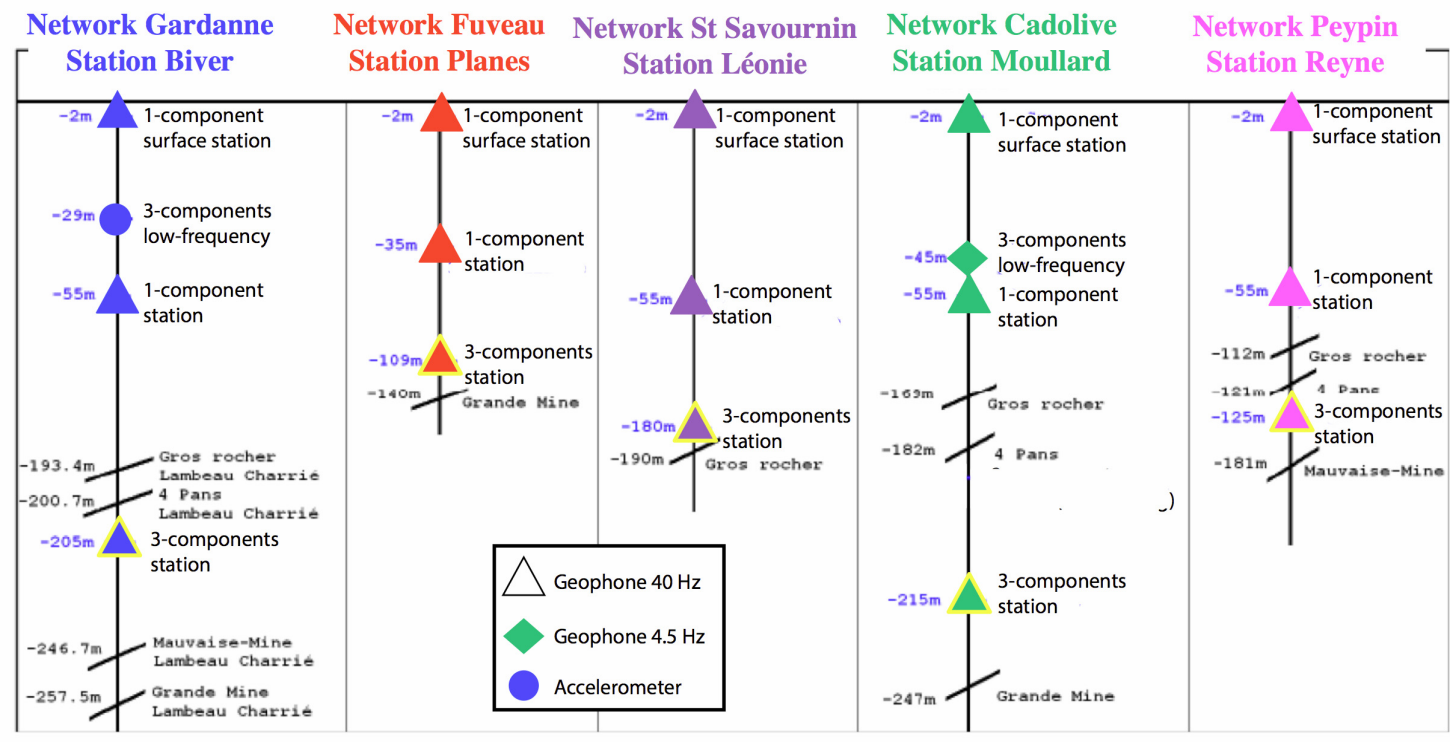

Figure 1 (a) Map of the recent seismicity (2008-2014) detected and located by INERIS. The colours of the circle are related to the duration magnitude taken from the catalogue. Several symbols are used for the different networks present in the area. The yellow circle represents the area of high population density of $400 \mathrm{~m}$ around the stations. The limit of the waterfront is also represented with a blue line. The red zone represents the extension of the "Grande mine" mine working layer. (b) INERIS permanent network configuration. 


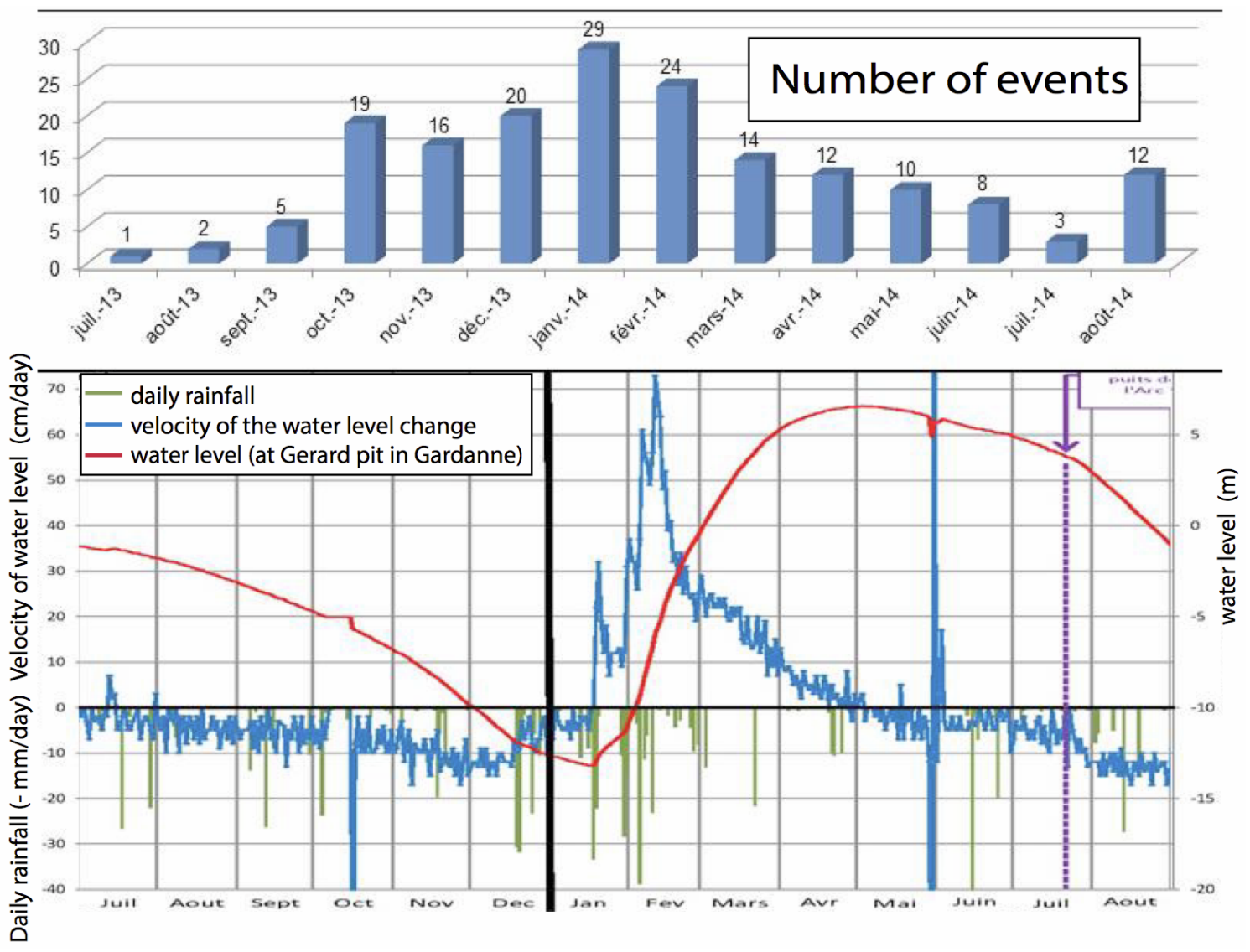

Figure 2 Correlation of the number of events detected by the BRGM temporary network on the crisis area (see red star on Fig. 1) (top figure) and (1) the daily rainfall (green), (2) the water level (red) and (3) the velocity of the water level change (blue) for the period July 2013-August 2014 (bottom figure). The daily rainfall is provided by METEO FRANCE, the number of events and the water level data are provided by BRGM-DPSM.

\section{Methods}

Such understanding of the faulting or underground mine collapse mechanisms needs accurate seismic event locations and precise determination of the focal mechanisms. In order to obtain reliable event locations and focal mechanisms of the low magnitude seismicity, an accurate 1D velocity model of the structure at depth is determined solving the coupled hypocenter-velocity inverse problem for more than 200 local earthquakes recorded. The station corrections reflect the inhomogeneous near-surface features.

In addition we tested and validated different methods of source localization, based on various data parameters (travel time, polarization, and combinations) using probabilistic approach (Contrucci et al., 2010; Lomax et al., 2000).

Spectral amplitude ratios will be analyzed to provide information on the types of focal mechanisms (tensile versus double-couple, Kinscher, 2015). The application of a general automatic moment tensor inversion approach (Dahm et al., 1999, Sen et al., 2013, e.g.) is very difficult for the high frequency microseismic data record because of the great complexity of the seismic signals. The source mechanism will be constrained by using an inversion approach considering the observed amplitude spectra of different stations in order to explore the best source model with respect to one single event (Kinscher, 2015). 
Spectral amplitude will be also used to determine the source seismic energies (seismic moment and magnitude) in order to calibrate a robust magnitude law. The data processing will be automated and applied at the whole dataset of events in order to obtain a complete catalog describing the evolution of the mine seismicity.

Particular attention will be paid on the two principal crises happened in November 2012 and December 2014 (Figure 1a). These two micro-earthquake swarming sequences repeatedly occur in specific sub-areas and appear influenced by the fluid migration. For this purpose, the distribution and space-time migration of the micro-seismicity will be analyzed in terms of variations in seismic wave propagation properties. In particular to better understand the role of the fluids in the fault failure process the ratio between compressional-wave and shear-wave velocity $(\mathrm{Vp} / \mathrm{Vs})$ will be analyzed.

\section{Conclusions}

Some preliminary analysis on the $\mathrm{Vp} / \mathrm{Vs}$ ratio and P-wave velocity model was performed. We found a high $\mathrm{Vp} / \mathrm{Vs}(1.85)$ and a 1D velocity model consistent with the lithologies present in the investigated area. Very small station residuals (between -0.05 and 0.05 ) are apparently related to the geometry of the mine. The analysis reveals and confirms the presence in the studied area of a carbonated layer partially fractured and permeated of water. The seismicity appears correlated with the waterfront. This suggest the high influence of the water migration on the micro-earthquakes triggering (Figure 2). The analysis on the source characterization will give more information about the fracture process.

\section{References}

Bennani, M., 2012. Note d'expertise complémentaire relative aux événements microsismiques ressentis en surface dans la zone de Fuveau - Gréasque, dans le bassin minier de Gardanne., note INERIS DRS_12-126881-12578A, pp. 17.

Contrucci I., Klein E., Bigarre P., Lizeur A., Lomax A., Bennani M., Management of post-mining large-scale ground failures : blast swarms field experiment for calibration of permanent microseismic early-warning systems. Pure and Applied Geophysics, 2010, 167 (1-2): p. 43-62

Contrucci, I., Bennani, M., Bigarré, P. \& Dominique, P., 2013, Activité microsismique et caractérisation de la détectabilité des réseaux de surveillance du bassin houiller de Gardanne, AGAP 2013, Nancy.

Contrucci, I., 2013. Détectabilité des réseaux de surveillance microsismique du bassin minier de Gardanne, rapport INERIS DRS-13-136284-07432A.

Dominique, P., 2014. Analyse préliminaire de la crise sismique de Fuveau (Bouches-du-Rhones), BRGM/RP-63592-FR.

Dahm, T., Manthei, G., and Eisenblatter, J. (1999). Automated moment tensor inversion to estimate source mechanisms of hydraulically induced micro-seismicity in salt rock. Tectono- physics, 306(1):1-17.

Kinsher J., 2015. PhD thesis. Analysis and interpretation of microseismicty induced by a collapsing brine mining cavity as a basis for progress in hazard assessment of inaccesssible underground cavities.

Lomax, A., J. Virieux, P. Volant and C. Berge, 2000. Probabilistic earthquake location in 3D and layered models: Introduction of a Metropolis-Gibbs method and comparison with linear locations, in Advances in Seismic Event Location Thurber, C.H., and N. Rabinowitz (eds.), Kluwer, Amsterdam, 101-134..

Sen, A. T., Cesca, S., Bischoff, M., Meier, T., and Dahm, T. (2013). Automated full moment tensor inversion of coal mining-induced seismicity. Geophysical Journal International, page ggt300. 